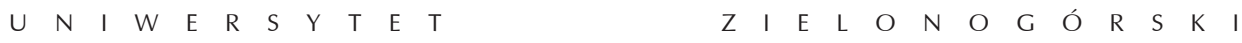

Przegląd Narodowościowy - Review of Nationalities

Jews $\mathrm{nr}$ 6/2016

DOI: $10.1515 / p n-2016-0014$

ISSN 2084-848X (print) ISSN 2543-9391 (on-line)

Krzysztof Łoziński*

\title{
The Jewish symbols
}

KEYWORDS: Jew, Judaism, symbol, archetype, Judaica

SŁoWA KLuczowe: Żyd, judaizm, symbol, archetyp, judaica

In every culture, people have always used symbols giving them sense and assigning them a specific meaning. Over the centuries, with the passage of time religious symbols have mingled with secular symbols. The charisms of Judaism have mutually intermingled with the Christian ones taking on a new tribal or national form with influences of their own culture.

The aim of this article is to analyze and determine the influence of Judaic symbols on religious and social life of the Jews. The article indicates the sources of symbols from biblical times to the present day. I analyzed the symbols derived from Jewish culture, and those borrowed within the framework of acculturation with other communities as well. By showing examples of the interpenetration of cultures, the text is an attempt to present a wide range of meanings symbols: from the utilitarian, through religious, to national ones. It also describes their impact on the religious sphere, the influence on nurturing and preserving the national-ethnic traditions, sense of identity and state consciousness. The political value of a symbol as one of the elements of the genesis of the creation of the state of Israel is also discussed.

"We live in a world of symbols, a world of symbols lives in us" Jean Chevalier

The world is full of symbols. They accompany us in our daily lives. We use them in different circumstances. We recognize them in the logos on our tablets, products purchased in the store. They show us certain information. There also exist in non-verbal

* BA in Political Science, Institute of Political Science, Faculty of Humanities, University of Zielona Góra. Mail: biuro@lozinski.pl. 
communication, small gestures and looks. We can see these older ones, hundreds years old, on the walls of ancient sacred buildings in the pages of books and manuscripts, carved in the stone inscriptions on the tombstones. They decorate all kinds of everyday objects; they are incorporated into the paintings and sculptures. We can find them in the styles of architecture, pages of literary works, finally, in the manner of dressing, behavior, taking a specific attitude and cultivating of rites. All of them speak to us, trying to give the content included in their symbolism. Whether they belong to the realm of sacrum or profanum they are a component and expression of the identity of the authors. Over the centuries, with the passage of time religious symbols have mingled with secular symbols. The ones of Judaism penetrated to Christianity. They accumulated, mutually permeated and united assuming a new tribal or national form tinged with influences of their culture.

Imponderables of Judaic national identity are derived from the centuries-old religion, tradition and a continuation of cohesion. We can not exactly specify them, and at the same time, we feel their influence on our conduct, core values and faith. Therefore, they do not have autotelic value - they only show another dimension of reality, different from what they represent themselves. For example, religious symbols, those related to the sphere of sacrum allow people to experience a mystical experience. They are a form of an image, which replaces an aspect. They move in a human being volitional ideas, thinking, associating, and often memories. We can not see their meanings solely in terms of allegory and reduce to the notion of an image or sign. That was already mentioned by the twentieth-century humanists: Carl Gustav Jung and Paul Tillich¹. They are „carriers” of a power greater than man's consciousness. The content of each of them is always open, ambiguous and can not be justified causally. A single motif or theme system has a hidden meaning in addition to the literal sense. Therefore, it does not have to have only one constitutive meaning. It may be understood in many ways, depending on the receiver and his perception. For example, the red color depending on the context can be a symbol of love (red rose, heart), blood (life and vigor), danger (stop sign), health (Red Cross, Red Crescent). Similarly, the color black can be associated e.g. with death (Christians), luxury (limousines color) or authority (judge's gown). In addition, the shape of the symbol, as well as its vertical position may contain a lot of hidden meanings.

1 More about the considerations what the symbol is, what distinguishes it from the allegory can be found in the works of C.G. Jung: Symbols of transformation, Archetype and the Collective Unconscious, Symbolic Life, Archetypes and Symbols, in P. Tillich's works Dynamics of Faith, Religious Symbol. 
Symbol is an essential element of the "language" of archetypes, combining it with consciousness. In terms of energy, the symbol is a "transformer of psychic energy," because it transforms and gives it expression in equivalent image terms ${ }^{2}$.

Among scientists, there is a discourse on the structural interpretation of the symbol as such, and what is still a sign and what is already a symbol? In epistemological, ethnographic, psychological or literary considerations, the obtained result will typically have a different dimension. Therefore, Paul Tillich's definition will be used to make clear what the symbol is. He pointed out that one of the features of the symbol is the fact that it is widely recognized as such. It is rooted and supported by the society ${ }^{3}$. The concept of the symbol by Władysław Stróżewski is also equally worth considering. For him, the symbol is an intentional object, which is constituted in a physical object, through specific cognitive acts, in particular acts of understanding and interpreting ${ }^{4}$. „Even in a seemingly rationalist culture of the modern West, characterized by a consumerist attitude towards life, and constantly new and changing fashions, universal symbols continue to determine the shape of our intellectual and emotional landscape. The desire to discover the interconnections of individual elements of the universe and the designation, which we find in it, are the internal, general human need, which connects us with the oldest ancestors" 5 . Even the ancient exploited symbols, which were immortalized in the form of talismans, hieroglyphics, objects and masks, to provide information about the history, life and death, about the divine and earthly. Symbolic messages were also included in the rituals, ceremonies, art and architecture. Predilection for symbolism occurred in all religions, which thus transmitted the dogmas of their faith.

Just in this mosaic of cultural diversity and national and ethnic diversity of landscape of characters and allegories, we find symbols of the Jews. Therefore, we should ask the question: who are the Jews and the Jewish people? Jews can be identified in several ways, which raises the possibility of conflict between their own personal identity, and their identity perceived by others ${ }^{6}$, „There are white, black, and Asian Jews; moreover, since the dawn of history extraneous element have played large role within their community" . If we assume that the Jews are a community, we can understand: followers of Judaism - as a religious community; Zionists - as a national community; those who feel themselves Jews and cultivate tradition - as a family community. Considering the question posed earlier through three types of identification: religious, national and cultural we can conclude that the uniform definition of a common Jew is not limited

2 C. Gustav Jung, Archetypy i symbole, Warszawa 1976, p. 21.

3 P. Tillich, Symbol religijny, Warszawa 1990, pp. 147-148.

4 W. Stróżewski, Próba ontologii symbolu, Kraków 1978, p. 105.

Święte symbole, R. Adkinson (edit.), Warszawa 2009, p. 7.

6 V. Descombes, Rozterki tożsamości, Warszawa 2013, p. 117.

7 L. Trepp, Żydzi - naród, historia, religia, Warszawa 2009, p. 17. 
to the discourse within the above directions. „The very notion of 'nation' implies the identification of internal and external classification"8. Belonging to the Jewish people on the basis of birth „of a Jewish mother” or both Jewish parents in Judaism is treated like a "citizenship”. The external classification is somewhat more difficult because there is not one consistent definition of the nation. Shlomo Sand, a Jew by origin, who is a professor of history at Tel Aviv University, believes that the Jewish nation has never existed, but was just invented ${ }^{9}$. It's quite brave, albeit not a very popular thesis. On the other hand, Stefan Dudra claims "people who think that they belong to the same nation create the nation ${ }^{10}$. Even if any version of the creation of the nation could be considered appropriate, it does not change the fact that the Jews have a huge both religious and cultural legacy. For centuries they have cultivated tradition, celebrated rites, used items symbolizing Jewishness. Among other things, they tried to preserve and strengthen the essence of Judaism and its ideas in this way. Jewish symbols hidden in objects, rites, art, literature, architecture and many other fields over the years have become the source of information about that which concerns the life and customs of the Jews. They have shown the history of everyday life, learning, work and death. To this day, they have been the bearer of memory about the origins of ancestors, and at the same time, they are an imperative which way the Jews should follow.

One of the prototypes of Jewish symbols is the Torah - the archetype of Judaism. This sacred scroll is the basic text of the Jewish religion, but other symbols of Judaism also derive from it. Their strictly defined order or importance does not exist. There is also no division between the more important and common. Everything depends in which aspect we consider the symbol, what we are referring to, or from what area of life it originates. Torah according to Jewish tradition is the book revealed, imparted to Moses on Mount Sinai as a sign of the covenant that God made with Israel. It consists of five books: Genesis - Sefer Bereshit; Exodus - Sefer Shemot; Leviticus - Sefer Vayikra; Book of Numbers (Numeri) - Sefer Bamidbar and Deuteronomy (Deuteronomium) Sefer Devarim. Five Books of Moses is not just limited to the display of religious law halakhah. "In fact, this is one of the central concepts in Judaism, functioning simultaneously on the levels of religious law, theology and mysticism"11.

8 Ł. Młyńczyk, Konstruowanie tożsamości politycznej w Polsce a mit o narodzie w kontekście rozważań Ernesto Laclau'a. Analiza dyskursywna, „Przegląd Narodowościowy - Review of Nationalities", No 2, 2013, p. 28.

9 More about this concept of creation of the Jewish nation in: S. Sandt, Kiedy i jak wynaleziono naród żydowski, Warszawa 2011.

10 S. Dudra, Łemkowskie „stawanie się narodem”, „Przegląd Narodowościowy - Review of Nationalities", No 2, 2013, p. 111.

11 A. Unterman, Żydzi. Wiara i życie, Łódź 1989, p. 40. 
There you will find a reference, for example, to the menorah - "And thou shalt make a candlestick of pure gold: of beaten work shall the candlestick be made: his shaft, and his branches, his bowls, his knops, and his flowers, shall be of the same"12. You will see an order placing at the door or gates to the house mezuzah - „And thou shalt write them upon the posts of thy house, and on thy gates"13. You will learn the importance of fringes fastened to a prayer shawl - tallit $(\mathrm{Nu} 15.39)^{14}$ and phylacteries - tefillin (Deut 6,4-8) ${ }^{15}$. Scroll of Torah - Sefer Torah - is the most sacred ritual object in Judaism. There are many traditions, rituals and rites associated with it, starting from the oral tradition, written later in the Mishnah, comments how to follow the Torah commands contained in the Talmud to the specific provisions concerning the prescription, storage and reading. Each of these activities is associated with a specific behavior and fulfilling the requirements of the Halakhah ${ }^{16}$. "Scroll of Rights is made namely with parchment, and not of any material, but with high quality parchment that is worthy of preserving the sacred word"17. The leather for the preparation of parchment can only come from animals that Jews are allowed to use for preparing ritual food. Rewriting, stitching individual pieces of skin, suitable formulation of ink, determined rewriting technique are the principles followed since immemorial times. The oldest fully preserved scroll is located in the university library in Bologna and is about 850 years old ${ }^{18}$. Pious reverence associated with the Holy Book is adhered not only during its production. Delicacy in handling and cordial care is maintained throughout the period of use of the scroll. It is carefully covered with a decorated case. Touching the scroll with hands is limited to a minimum, and accordingly it is stored in the closet altar - Aron ha-Kodesh, which symbolizes the Ark of the Covenant. Public reading is performed in such a way that the whole Pentateuch is read within one year. Reading of the Torah is the task of the

12 Source: http://www.kingjamesbibleonline.org/ (Exodus 25,31).

13 Ibidem, (Deut 6,9).

14 Ibidem, "And it shall be unto you for a fringe, that ye may look upon it, and remember all the commandments of the LORD, and do them; and that ye seek not after your own heart and your own eyes, after which ye use to go a whoring:".

15 Ibidem, "4. Hear, O Israel: The LORD our God is one LORD: 5. And thou shalt love the LORD thy God with all thine heart, and with all thy soul, and with all thy might. 6 . And these words, which I command thee this day, shall be in thine heart: 7. And thou shalt teach them diligently unto thy children, and shalt talk of them when thou sittest in thine house, and when thou walkest by the way, and when thou liest down, and when thou risest up. 8 . And thou shalt bind them for a sign upon thine hand, and they shall be as frontlets between thine eyes".

16 A. Unterman, Żydzi. Wiara i życie, Łódź 1989, „halacha - Żydowska droga. Czesść nauki żydowskiej zajmującej się rytuałem normami postępowania; prawna strona judaizmu”, p. 285.

17 Rabin Simon Philip DeVries Mzn., Obrzędy i symbole Żydów, Kraków 1999, p. 32.

18 www.timesofisrael.com/hebrew-profs-weigh-in-on-important-12th-century-find/, 29.03.2015. 
designated man - kore, or a cantor - chazan can perform that activity in the presence of 10 Orthodox Jews ${ }^{19}$.

„The institution of the synagogue appeared during the Babylonian captivity, after the destruction of the First Temple of Jerusalem. It became a central element in Jewish public life after the destruction of the Second Temple. Nowadays it is an inseparable component of the Jewish communal religious life, and for some modern Jews it has even replaced their home in its ritual role" 20 . In ancient Greek The synagogue means a place of assembly, meeting place. The equivalent in Hebrew is Beit ha-Knesset - the house of assembly, meeting place. It is not a synonymous with the temple in the Christian notion. Inside people do not worship the holy and do not sacrifice. It can be an imposing building with stained glass or ordinary home transformed into a synagogue. It is a venue where both prayers and meetings of the Jewish community take place. It is designed to teach and study the Torah and the Talmud - Beit ha-Midrash, but as a simple meeting room for the Jewish community as well. Formerly in the synagogues, there were rabbinical courts, offices, kosher cafeteria, and even night shelters. Its primary function is the place to study and pray, though. However, the knowledge, and thus learning the Hebrew language was needed in order to participate in the prayers of the community, to participate actively in religious ceremonies. For each nation the language is an important element of their identity ${ }^{21}$. All the rites are celebrated in that language. „The protection and storage of the language is still protection and preserving the soul of the nation. It also means concern for the unity of the nation. Hebrew as the community language of the synagogue provides such a kind of relationship in an incomparable way" 22 . The fact that since the establishment of the state of Israel the Hebrew language, once used for prayer and writing religious texts, has been its official language shows its strength. While so common years ago in the diasporas the Yiddish and Ladino languages are today less and less known ${ }^{23}$. In this way, a place of learning and prayer enabled cultivating Jewish tradition and culture. Once you cross the threshold of a synagogue and find yourself inside it you can see fixed, immutable principles of its arranging. It is divided into two parts: one for women and one for men. Men occupy a place in the middle of the room. Women will be in the gallery or a platform

19 Minyan - prayer quorum required for certain religious rituals. What is needed is the presence of ten adults, i.e. older than 13 years, Orthodox Jews - it is associated with the belief that in minyan God is present, as it did in the Temple of Jerusalem. Reform, Conservative and Reconstruction Judaism also accept women to minyan.

20 A. Unterman, Żydzi. Wiara i życie, Łódź 1989, p. 240.

21 P. Pochyły, Źródła tożsamości narodowej Kurdów, „Przegląd Narodowościowy - Review of Nationalities", No. 2, 2013, p. 123.

22 Rabin Simon Philip DeVries Mzn., Obrzędy i symbole Żydów, Kraków 1999, p. 27.

23 Almost 5.4 million people use Hebrew while only a bit more than 1.5 people use Yiddish. Data from www.ethnologue.com, 29.03.2015. 
next to men. Whether the place will be on one or both sides or behind men stems only from its architecture. In the middle of the synagogue, there is a platform - bima. The platform resembles the teacher's desk in the classroom. It is the place of reading the Torah. At the east wall inside the synagogue there is always "Holy Ark", i.e. an altar cabinet, referring to the box of the Temple of Solomon, in which stone "tablets of the covenant" were stored.

The inherent equipment of a synagogue is the lamp, where light is constantly smoldering - ner-tamid. "Eternal Light" is a reference to the burning fire of the golden candlestick from The Tabernacle of The Congregation in The Sanctuary of The Temple. There is no specific shape or pattern of ner-tamid. It refers to the commemoration of the menorah from the first Sanctuary of the Temple in Jerusalem, and is also a symbol of the soul of man and his duties in life ${ }^{24}$. Menorah is undoubtedly one of the oldest symbols of the Jewish people, and this has also become one of the most common and recognizable signs of the Jews, not only religious but secular as well. Depending on the religious or historical context this seven-branched candelabrum refers to the biblical burning bush that Moses saw on Mount Sinai (Exodus 3.2) ${ }^{25}$ may be also considered to be a divine light for the chosen people, and seven of its arms is a reference to the eyes of the Lord, who looks at the earth (Zechariah 4.10) ${ }^{26}$. The shape of the candlestick also evokes associations to the tree of life from the Garden of Eden. Its arms represent: understanding, strength, fear of God, the divine presence, knowledge, advice and wisdom. The exact description of what it should look like, is the commandment in Exodus $(25,31-40)^{27}$, as well as in the Book of Zechariah (4.2) ${ }^{28}$. Since the establishment of the state of Israel, menorah has been part of the state emblem. Its image is placed on passports, on the boards of offices and courts, as well as official documents of the state and countless souvenirs from Israel. According to prof. Stanisław Krajewski of the Jewish Historical Institute, the menorah is "an essential symbol of Judaism". An exact replica of the golden menorah from the period of the Second Temple is placed near the Wailing Wall in Jerusalem. A nine-branched candelabrum - chanukiah also refers to the original appearance of the menorah. This candlestick is lighted during Hanukkah holiday

24 Source: http://www.kingjamesbibleonline.org/, 26.03.2015, “The spirit of man is the candle of the LORD, searching all the inward parts of the belly..", (Prov. 20,27), and also "For the commandment is a lamp; and the law is light; and reproofs of instruction are the way of life:". (Prov. 6,23).

25 Ibidem, "And the angel of the LORD appeared unto him in a flame of fire out of the midst of a bush: and he looked, and, behold, the bush burned with fire, and the bush was not consumed".

26 Ibidem, "For who hath despised the day of small things? for they shall rejoice, and shall see the plummet in the hand of Zerubbabel with those seven; they are the eyes of the LORD, which run to and fro through the whole earth".

27 Ibidem.

28 Ibidem, 2. "And said unto me, What seest thou? And I said, I have looked, and behold a candlestick all of gold, with a bowl upon the top of it, and his seven lamps thereon, and seven pipes to the seven lamps, which are upon the top thereof". 
and commemorates events related to the Maccabean Revolt. Hanukkah has evolved over the years, partly also into a form of secular and military holiday of all Israel. It falls on the 25th day of the month of Kislev (in the Gregorian calendar this time falls on November - December) and for the next 8 days, people light one candle. At this time, they also give children gifts, cash and sweets. Moreover, the custom of gambling playing cards or a game dreidel is very popular ${ }^{29}$.

Entering the house inhabited by the Jews, we can see in the right frame of the door a small, oblong and decorated box. It is fastened at an angle, to the human eye height so that it is visible to everyone entering. The box can be made, depending on the wealth of the host, from ivory, glass, metal, or in the case of quite poor home from the usual cardboard. Inside there is a sheet of parchment with a piece of daily prayers written by a sofer - the Shema Israel, as the Torah commands (Deut 6,4-9 and 11.20) ${ }^{30}$. Many devout Jews when they were entering and leaving the house touched the mezuzah with tips of their fingers then kissed them. It was an expression of respect and warship for the word. A mezuzah was supposed to remind them of God's omnipotence, guard as a shield peace of the house and its inhabitants. In folk beliefs, it was a kind of talisman protecting family members from harm. It is to be a sign of reminder, always visible, eye-catching that constantly says, „Hallowed be your home! Let your house is just neither a roof, nor your castle: let it be your temple"31.

They are, similar in the form of boxes, though less well known than the mezuzah, attached to the forehead between the eyes and the left forearm in time of prayer (Deut $6,8)^{32}$. Two black leather boxes, connected with a leather strap are tefillin - prayer items also called phylacteries. Inside them there are texts of the four prayers from Exodus 13,1-10 and 11-16 as well as the Deuteronomy 6,4-9 and 11,13-21. Interestingly, in both these little boxes there are texts of the same prayers. However, in this one worn on the hand, which is directed towards the heart to symbolize the mutual relationship, as well as the armed arm (not with a shield, but the Word of God) - the text is written on a piece of parchment. The box placed between the eyes, which indicates the harmony of God's Word and intellect contains prayers written each on a separate parchment. Additionally during prayers, Jews cover their heads or arms with a prayer shawl - tallit. It is usually white with blue stripes along the sides. The color refers, depending on the perception of the audience, to the tribe of Judah, the purging importance of water or the sky. The most important elements of tallit are fringes - tzitzit, attached to the edge

29 A dreidel is a Jewish variant on the teetotum, a gambling toy. Each side of the dreidel bears a letter of the Hebrew alphabet: nun, gimel, hej, pej which are the acronym of Nes Gadol Hayah Poh-"A great miracle happened here".

30 Source: http://www.kingjamesbibleonline.org/, 26.03.2015.

31 Rabin Simon Philip DeVries Mzn., Obrzędy i symbole Żydów, Kraków 1999, p. 78.

32 Source: http://www.kingjamesbibleonline.org/, 26.03.2015. 
of the shawl. They symbolize the commandments of the Lord contained in the Book of Numbers (Numbers 15,38-41) 33 . Threaded through tallit, laced thread, and in a certain way bound they give a figure of 39 knots. "It corresponds exactly to the number, which the letters of the expression Adonai echad form, when they are read as numbers in the system of numbers and letters corresponding in meaning to each other. These words mean the following: Adonai - i.e. The Eternal is one. According to the wisdom of the Talmud, the person who has the three signs above-mentioned placed at home, on the forearm and forehead and a mark on clothes, is hardly able to sin.

One of the most recognizable Jewish symbols is kipa - in the Hebrew language "dome". Nevertheless, the most frequent used is a skullcap, a small cap covering only the top of head. The black ones are worn for everyday use, but the colorful ones, sometimes with fairy tale or movie motifs for children and youth. are used on special occasions. The order to wear them is not associated with religious duty and is rather customary. You would not find possible recommendations in the Talmud and the Torah. There are many theories associated with sources of when the Jews began to wear kipas. Some see this in traditional headgears of Babylonian scholars, others in a high priest outfit. There are theories referring to the custom of covering the head by the servants in the Middle East and the analogy to the service of God. The sources of this tradition can also be stuck in the medieval order for Jews to wear a headgear in public. Perhaps the coercion became a symbol of this part of society. For many years the covering itself took on different forms and shapes. Widespread were black wide-brimmed hats, fur shtreimels, then quite distinctive caps. Current kipas, depending on the material they are made of, and the color can symbolize: Orthodox Jews, conservative or Hasidism Jews. Crocheted kipas - kipa sruga become increasingly popular, especially among religious youth The headgear is an excellent example of how a symbol can evolve over the years, changing its form and shape at the same time indicating and specifying the same values.

Today, the most recognizable symbol of the Jews is a six-pointed star, called the Star of David - Magen David (Hebrew. The Shield of David). In the distant past and it did not play as significant and common role as it does today. Although the oldest monument, where you see the six-pointed star, is a relief formed around the seventh century

33 Source: http://www.kingjamesbibleonline.org/, 26.03.2015, “38. " Speak unto the children of Israel, and bid them that they make them fringes in the borders of their garments throughout their generations, and that they put upon the fringe of the borders a ribband of blue: 39 . And it shall be unto you for a fringe, that ye may look upon it, and remember all the commandments of the LORD, and do them; and that ye seek not after your own heart and your own eyes, after which ye use to go a whoring: 40. That ye may remember, and do all my commandments, and be holy unto your God. 41. I am the LORD your God, which brought you out of the land of Egypt, to be your God: I am the LORD your Go". 
BC which was found during archeological work in the vicinity of Sidon in Lebanon, its image spread in earnest in the Middle Ages to the sacred objects, the grave art and in the Jewish Kabbalah. There is a dispute among researchers about the origin of the sign. It appears on the boards of the Sumerians, in the Hindu mandala, in Buddhism, on the Maya citadel, in Christian churches as well as coins - Phoenician, Tibetan, and even Muslim dirhemach. Since 1897 it has been functioning as the official symbol of the Zionists. During World War II, under the Regulation of General Governor Hans Frank on December 1, 1939, all the Jews who were over 10 years old were obliged to wear on the shoulder white armbands with the Star of Zion. The creation of Israel in 1948 gave a new meaning to the Jewish symbols, as well as strengthened the sense of national community. Then Magen David and the menorah became not only a religious and national symbol, but received the state status. The Star of David is part of the national flag of Israel, and the seven-branched candelabrum is in its emblem.

Among the symbols of the Jews there are also many customs and rituals characteristic for them. Shabbat and all the duties associated with it, Jewish holidays: New Year Rosh Hashanah, the day of Yom Kippur, Sukkot, or the Feast of the Passover - Pesach and Hanukkah and Purim. A ritual meal preparation (kasher) is extremely important in Jewish life, from the proper deprivation of life of the animal - shekhita, through its examination and approval of kashrut, the separation of meat and milk and use the appropriate cookware. Already at the beginning of life the newborn Jew, eight days after the birth takes place the custom of circumcision. A ceremony of Mar Mitzvah is held in connection with the completion of 13 birthday of a Jewish boy and the same on the 12 birthday for girls Bat Mitzvah. They are symbols of their passing into the adult world, as well as confirmation of the possibility of taking an active part in important religious ceremonies - they may be members of the minyan, and are entitled to enter into marriage, to testify before rabbinical courts, etc. Then the wedding; chupa and mazel tov. The life that goes on from cradle to grave is marked by following of tradition, the primary focus around Jewish heritage and transmission to future generations. Even after their death by the information outlined on the gravestones, the Jews passed on their values and ideals to their descendants. Jewish cemeteries are a place where memory meets national and ethnic community. They are a place where not only an old tradition is saved, but also a place where suitable meaning is given to death, indicating the grounds for a present identity.

More than 400 of the 1,200 Jewish cemeteries (kirkut ${ }^{34}$ ) that existed on Polish territory before the war did not survive. Tombstones from the Jewish cemeteries were used

34 A word derived from the German language, specifying the Jewish cemetery. Other words used in literature: kierkow, kierchol, kirchol. There are also such names In the Hebrew language as: bejt olam - "the house of light", bejt kwarot - "the house of graves", bejt almin - "the house of 
to repair streets and sidewalks, construction of buildings. The wood steles were used for fuel which irreversibly destroyed them. Many Jewish cemeteries were turned into parks, lawns, squares and fountains. Until recently, those that survived were covered with tall grass, trees and dense thicket. Traces of Jewish culture were hidden among these wild shrubs. They were on the tombstones - matzevahs. Intricately carved in stone by unknown artists and artisans the reliefs are not only artistic or decorative. These inscriptions also contain a symbolic element concerning the characteristics of the deceased, his family, profession or class and which Jewish community he came from. Throughout history, gravestones took on many forms, from a pile of laid stones to the column or table. The materials from which they were made differed depending on availability in the area, or financial status of the family. There were also cave graves forged in the rock, sarcophagi for important people or graves in the catacombs ${ }^{35}$. In the article I will present only the inscriptions on the tombstones, which in their form were the most prevalent.

The oldest tombstone presented in the Bible is the one placed on the grave of Jacob and Rachel standing on the road to Bethlehem. "And Jacob set a monument on the grave of her; it is a monument to the tomb of Rachel, to this day" 36 . According to the Hebrew Bible Matzevahs are not just a sepulchral stone. They are also stone tables and columns posed by people to commemorate a person or to commemorate an event ${ }^{37}$. We do not know exactly what the original stone tablets or columns looked like. Were they just hewn stones or decorated with inscriptions like those discovered in the ruins of the ancient Canaanite city in the vicinity of Kibbutz Gezer, located halfway between Jerusalem and Jaffa? Information about the monumental stone tombs can be found in such Apocrypha as the First Book of Maccabees, and Josephus Flavius ${ }^{38}$ described them. The gravestones were also placed as a tribute to himself while the person's life and to commemorate his name ${ }^{39}$. According to AndrzejTrzciński to the mid-sixteenth

eternity", or because the cemetery in the Jewish culture is considered an impure place they use the euphemism bej chajm - "the house of life".

35 Outside Palestine, there were catacomb cemeteries among others in Rome, Carthage, Malta and Sicily from the second to the ninth century.

36 Source: http://www.kingjamesbibleonline.org/, 26.03.2015, (Genesis 35.20).

37 Ibidem. A stele placed in memory of the meeting of Jacob with God - " And Jacob set up a pillar in the place where he talked with him, even a pillar of stone: and he poured a drink offering thereon, and he poured oil thereon."(Genesis 35.14), or stone slab commemorating the meeting of Moses with the Angel of the Lord -" And Moses wrote all the words of the Lord, and rose up early in the morning, and built an altar under the hill, and twelve pillars, according to the twelve tribes of Israel."(Ex 24.4).

38 J. Flawiusz, Wojna żydowska, Warszawa 1991, pp. 61-62 and p. 322.

39 Source: http://www.kingjamesbibleonline.org/, 26.03.2015, "Now Absalom in his lifetime had taken and reared up for himself a pillar, which is in the king's dale: for he said, I have no son to keep my name in remembrance: and he called the pillar after his own name: and it is called unto this day, Absalom's place." (2 Sm 18.18). 
century and in the provinces, even to the seventeenth century decorative motifs on the tombstones were rare ${ }^{40}$. Only after this period, „modern tradition of decorating graves with symbolic representations begins to take shape. Artistic themes take an important and consistent position on the tombstone and eventually become an equivalent and sometimes dominant element of the composition in relation to the field with the inscription" ${ }^{41}$. Since that time, a number of ethnic and folk symbols present in the various diasporas have appeared on tombstones. In addition to the typical Jewish symbols like the menorah or a pentagram decorations referring to folk beliefs and legends began to appear on gravestones. Richness of symbolism on stone stele referred to the life of the deceased, his status, interests, profession, but also his personal qualities, reflection of passing. You can find on them motives corresponding to the biblical stories, the sphere of worship and many of the laity elements. Putting tombstone in addition to the undoubted benefits of utilitarian as protecting a tomb and marking the burial site for posterity is a form of veneration of the dead and care for his soul, and with time adopted as a obligatory - a religious duty. Only in Poland, about 100 themes with hidden Jewish symbols can be found in Jewish cemeteries. It may seem, especially for people who do not know the subject of the Jewish sepulchral art that the frame engraved on the plate of matzevah is an ordinary art rim, as if trying to close the area with inscriptions and carved symbols. Nothing could be further from the truth. This border has many different meanings. Starting from the use of ancient, architectural scheme of aedicula - a kind of chapel, also refers to the symbol of the gateway to heaven ${ }^{42}$ or Torah scroll wound on the rollers. The gate can also be a reference to the Jewish tradition based on the prophecy that Messiah will come to Jerusalem through the Golden Gate. The Golden Gate - Bab al-Rahma, is the only gate leading directly to the Temple Mount and the Mount of Olives ${ }^{43}$. In the case of graves of rich Jews, magnificent tombs were built instead of a stone stele. Carved earlier in the frame in the form of architectural columns and arch it transformed into real columns, and the carved arch into a real niche or dome over the grave. Despite these changes, the symbol of the gate and its importance remained unchanged. The theme of placing on the tombstones the symbolism of the gate was a universal value indicating the first symbol of transition from one place to another, from one existence to another. Secondly,

40 A. Trzciński, Symbole i obrazy. Treści symboliczne przedstawień na 18 nagrobkach żydowskich $w$ Polsce, Lublin 1997, p. 22.

41 Ibidem.

42 Psalmy, translated by. I. Cylkow, Warszawa 1883, „Oto wrota Boże, cnotliwi niech wejdą w nie.", p. 343.

43 The Golden Gate is one of the eight gates of the Old City of Jerusalem. In the Middle Ages, Jews prayed in front of the Golden Gate like Jews today pray in front of the Wailing Wall. 
it had the function of sanctifying relating to faith and religious beliefs. Thirdly, it had other, depending on the recipient, variants of interpretation.

The most common groups of symbols on Jewish gravestones are associated with the wine and vines, but first of all the tree has a special place. „It was associated with abundance, stability, strength in the archetypal imagery. It entered idiomatic expressions through its fruit: the fruit of one's labor, the fruit of the reflection etc. In proverbs - such as „strong as an oak” - means power ${ }^{44}$. Displaying the symbol of tree on the graves also has a spiritual character, closely associated with the Jewish religion. Its archetype is planting the tree of life by God in the middle of the Garden of Eden ${ }^{45}$. Israel was also compared to the tree (Num 24, 5-6) ${ }^{46}$. In the symbol of the tree Jews also saw religious and just people (Proverbs 11.30$)^{47}$ or happy (Proverbs 3:18) ${ }^{48}$. There are many more of such references not only in the Torah, but also in the non-canonical writings and other post-biblical literature. The symbol of tree in the sepulchral context has a vanitative character. The tree on tombstones reminds of the futility of life on earth and passing. It indicates that nothing is permanent, and at some point, it ends under the law of passing. For religious Jews it was a reference to the Paradise tree of life and its immortal fruit (Gen 2.9) ${ }^{49}$ or the tree of the knowledge of good and evil (Genesis 2,16-17 ${ }^{50}$. "The Tree of Life” is understood as a natural gift of immortality and as the tree "of knowledge of good and evil” is seen as an indicator of what is good and what is bad. All these trees are shown broken in half. They mean the end of life on earth and reference to the Book of Ecclesiastes from the Hebrew Bible - the Tanakh. Similarly, motives of vine and wine are important in Judaism. Judaism prohibits the presentation of human beings in art hence they were replaced by the symbol of human hands. The way of presenting hands shows the existing links with the life of the deceased. The characteristic element of gravestones of descendants of families of priests - kohens is hands arranged in a gesture similar to the blessing, with clasped thumbs of both hands

44 K. Bardski, W kręgu symboli biblijnych, Kraków 2010, p. 35.

45 Tora - Pięcioksiąg Mojżesza, translated by I. Cylkow, Kraków 2010, I wywiódł Wiekuisty Bóg z ziemi wszelkie drzewo urocze na wejrzenie i smaczne ku spożyciu, - drzewo też życia w pośrodku ogrodu, i drzewo poznania dobrego i złego. p. 11.

46 Source: http://www.kingjamesbibleonline.org/, 5, 26.03.2016, "How goodly are thy tents, $\mathrm{O}$ Jacob, and thy tabernacles, O Israel! 6 "As the valleys are they spread forth, as gardens by the river's side, as the trees of lign aloes which the LORD hath planted, and as cedar trees beside the waters".

47 Ibidem, "Fruit of the righteous is a tree of life, and a wise man wins the souls".

48 Ibidem, "She is a tree of life to them that lay hold upon her: and happy is every one that retaineth her".

49 Ibidem.

50 Ibidem, 16. And the LORD God commanded the man, saying, Of every tree of the garden thou mayest freely eat: 17 But of the tree of the knowledge of good and evil, thou shalt not eat of it: for in the day that thou eatest thereof thou shalt surely die". 
and fingers spaced slightly apart. In the gesture you can also see the symbol of a triangle, or a pyramid. Thus, one symbol, exactly when we analyze it thoroughly and try to read its message generates successive symbols. A hand lifting a jug of water above the bowl, with pouring water out of it, symbolizes the descendants of the Levites ${ }^{51}$, who as the temple helpers washed the priests' hands. The hand holding a quill, a book or a cupboard with books symbolizes the tomb of a writer or scholar. Additionally, in the case of a scholar reading the Torah on the tombstone there is a sign showing the $\mathrm{yad}^{52}$ a ritual pointer of the shape of the hand. Similarly, if we find the lancet used to circumcision on the tomb, we can be sure that it the grave of a mohel - ritual slaughterer. In the case of mohel, we can also see an image of "Elijah's chair"53 - kise shel Eliyahu.

On the graves of Jewish women, there are often candles and a seven-branched candelabrum - menorah. Candles are broken ${ }^{54}$ or with an extinguished wick. This symbolizes death as the end of life on earth. The candelabrum symbolizes the woman lit the Sabbath candles in her lifetime. Animals were a frequent theme, i.e. the Bible ones like a lion, snake, tiger, deer and the legendary leviathan. We can also see the animals living in areas where the tomb is. They refer to the blessings of Jacob, sometimes the names of the dead. Animal characters symbolize the religious events. They can also refer to patronymic name of the deceased. Many popular Jewish (Hebrew) names translated into Yiddish and German define animals: lion - Ari, Leib; deer - Zvi in Yiddish, Hersh in Hebrew. Themes are on the tombstones, creating together a sort of stories about the deceased and their lives. In addition to symbols, an essential element of the gravestones is an inscription written mostly in Hebrew. The date of death is added to the name. It does not have any digits, but Hebrew letters. Sometimes words expressing grief over the loss or literary epitaphs are also added. On the stele, we very often see ornaments in many other forms: a crown, a lion, a unicorn or a piggy bank, which in combination with poetic epitaphs symbolize ethnic and professional origin of the Jews buried there.

The Jewish population for almost 4,000 years of its history has been moving into different regions of the world. The ancient Hebrews wandering from Mesopotamia through Egypt came to Canaan ${ }^{55}$ experienced their culture flourishment during the reign of kings David and Solomon. There were also failures like the so-called Babylonian

51 Levites - descended from Levi, served particular religious duties in the Temple and had political responsibilities as well.

52 Yad (Hebrew hand) a Jewish ritual pointer, used by the reader to follow the text of Torah so that he does not touch it.

53 Ornate chair or armchair, on which (implicitly) the prophet Elijah sits during ritual circumcision.

54 The symbols of a broken tree, broken flower, a broken crane at the well have similar importance of mourning and end of life.

55 Nowadays Palestine. 
captivity, which initiated the formation of the Jewish Diaspora in the world. This dispersion, and the different conditions in which they lived, contributed to the creation of a different ethnic culture. Ashkenazi Jews living in Central and Eastern Europe created the Yiddish language, Sephardic Jews from the Iberian Peninsula created the Ladino language. There was also a relatively small group of Oriental Jews - Mizrahi, who lived in North Africa and the Middle East, and dark-skinned Ethiopian Jews - Beta Israel. It did not stand in the way to preserve the common heritage and Judaic culture. Their common religion was a determinant of behavior not only religious, but also ethnic. Focusing around Jewish symbols, cultivating traditions and rituals helped to survive thousands of years. Despite acts of resentment and hostility to the Jews, depending on the place of settlement they tried to assimilate to the local conditions. „Cultural behavior characteristics” are passed from one community to another by „dispersion”, in other words - by the type of infecting units by the others ${ }^{56}$. Jews contributed to the development of local cultural traditions. Today's paper cutouts from Łowicz region have their prototype in Jewish culture. Similarly sweet, tasty chatka is ritual bread for the Jews. Elements of culture, traditions and beliefs permeated the other way. Mixed marriages were not too seldom, many of the words of the Yiddish language have their origins in the Slavic languages. Also in Judaic demonology, there are references to Slavic beliefs. Malignant "Południca" hunting the people staying on the field at noon became a prototype for Jewish Lilith. Robes worn by the Haredim is the successor of the old Polish zupan. People assumed many proverbs and folk tales as their own only substituting the names of Jewish heroes. Despite the direct influence and penetration of cultures, Jews were able to maintain consistency and religious tradition. In all this, "symbols play a key role, expressing the common belief, strengthen people in their faith, yet are sufficiently abstract to allow each entity to own their interpretation" ${ }^{2}$. Consistent cultivating these traditions can build a lasting chain of generations. There are also many new, created relatively recently Jewish symbols. Number tattooed on somebody's forearm - the symbol of the Holocaust, yellow daffodils plugged in the lapel emphasizing the memory of the uprising in the Warsaw ghetto.

Many Jewish symbols have their counterparts in other cultures or religions. The trees of life and death; headdress starting from the crown and ending at the ornamental caps; fire; hands; animals or clothing from the beginning of time, regardless of the religion have presented their own belief system. Since the dawn of history, stories about the natural and supernatural world have been presented inter alia by means of rituals, art, talismans, architecture and music. Their task was to maintain the community in the unity and closeness. Among others, symbols strengthen the sense of national identity

56 V. Descombs, Rozterki tożsamości, Warszawa 2013, p. 101.

57 M. Jordan, Tajemnice kultur i religii Wschodu, Warszawa 2000, p. 94. 
and indicate the values important for Judaism. Thanks to them Jews build community centered on national tradition, and finally their common heritage that unites them all over the world focuses around the symbols. Their thousand-year tradition revives constantly in their rituals and symbols. The creation of the state of Israel and strong Jewish Diaspora only confirms the strength and power of meaning.

\section{Bibliography}

Bardski K., W kręgu symboli biblijnych, Kraków 2010.

De Vries Mzn S.P., Obrzędy i symbole Żydów, Kraków 1999.

Descombes L., Rozterki tożsamości, Warszawa 2013.

Dudra S., Łemkowskie „stawanie się narodem”, „Przegląd Narodowościowy - Review of Nationalities”, No 2, 2013.

Flawiusz J., Wojna żydowska, Warszawa 1991.

http://www.kingjamesbibleonline.org [access: 29.03.2015].

http://www.timesofisrael.com/hebrew-profs-weigh-in-on-important-12th-century-find/ [access: 29.03.2015].

Jordan M., Tajemnice kultur i religii Wschodu, Warszawa 2000.

Jung C.G., Archetypy i symbole, Warszawa 1976.

Jung C.G., Symbols of transformation, Archetype and the Collective Unconscious, Symbolic Life, Archetypes and Symbols, [in:] P. Tillich's works Dynamics of Faith, Religious Symbol.

Młyńczyk Ł., Konstruowanie tożsamości politycznej w Polsce a mit o narodzie w kontekście rozważań Ernesto Laclau'a. Analiza dyskursywna, „Przegląd Narodowościowy - Review of Nationalities”, No 2, 2013.

Pochyły P., Źródła tożsamości narodowej Kurdów, „Przegląd Narodowościowy - Review of Nationalities", No. 2, 2013.

Psalmy, translated by. I. Cylkow, Warszawa 1883.

Sandt S., Kiedy i jak wynaleziono naród żydowski, Warszawa 2011.

Stróżewski W., Próba ontologii symbolu, Kraków 1978.

Święte symbole, R. Adkinson (edit.), Warszawa 2009.

Tillich P., Symbol religijny, Warszawa 1990.

Tora - Pięcioksiąg Mojżesza, translated by I. Cylkow, Kraków 2010.

Trepp L., Żydzi - naród, historia, religia, Warszawa 2009.

Trzciński A., Symbole i obrazy. Treści symboliczne przedstawień na n18agrobkach żydowskich w Polsce, Lublin 1997.

Unterman A., Żydzi. Wiara i życie, Łódź 1989.

\section{The Jewish symbols}

ABSTRACT

In every culture, people have always used symbols giving them sense and assigning them a specific meaning. Over the centuries, with the passage of time religious symbols have mingled with secular symbols. The charisms of Judaism have mutually intermingled with the Christian ones taking on a new tribal or national form with influences of their own culture.

The aim of this article is to analyze and determine the influence of Judaic symbols on religious and social life of the Jews. The article indicates the sources of symbols from biblical times to the present day. I analyzed the symbols derived from Jewish culture, and those borrowed within the framework of acculturation with other communities as well. By showing examples of the interpenetration of cultures, the text is an attempt to present a wide range of meanings symbols: from the 
utilitarian, through religious, to national ones. It also describes their impact on the religious sphere, the influence on nurturing and preserving the national-ethnic traditions, sense of identity and state consciousness. The political value of a symbol as one of the elements of the genesis of the creation of the state of Israel is also discussed.

\section{Symbole żydowskie}

STRESZCZENIE

W każdej kulturze od zawsze posługiwano się symbolami nadając im sens i przypisując im określone znaczenie. Na przestrzeni wieków, wraz z upływem czasu symbole religijne mieszały się z symbolami świeckimi. Chryzmaty judaizmu wzajemnie przenikały się z chrześcijańskimi przybierając nową plemienną lub narodową formę zabarwioną naleciałościami własnej kultury.

Celem artykułu jest analiza i określenie wpływu symboli judaistycznych na życie religijne i społeczne Żydów. Wskazano praźródła symboli od czasów biblijnych do współczesnych. Analizie poddano symbole wywodzące się z kultury żydowskiej jak również i te zapożyczone w ramach akulturacji z innymi społecznościami. Tekst poprzez pokazanie przykładów przenikania się kultur jest próbą przedstawienia szerokiego spektrum znaczenia symboli od utylitarnych poprzez religijne, aż do symboli narodowych. Opisuje również ich oddziaływanie na sferę kultu religijnego, wpływu na pielęgnowanie i utrwalanie tradycji narodowo-etnicznych, poczucia tożsamości oraz na świadomość państwową. Omówiona zostanie również wartość polityczna symbolu, jako jednego z elementów genezy powstania państwa Izrael. 